\title{
DESAIN NON-PLAYER CHARACTER PERMAINAN TIC-TAC-TOE DENGAN ALGORITMA MINIMAX
}

\author{
Gunadi Emanuel $^{1}$, R. Kristoforus J. Bendi ${ }^{2}$, Arieffianto ${ }^{3}$ \\ Universitas Katolik Musi Charitas ${ }^{1,2,3}$ \\ Jalan Bangau No. 60 Palembang \\ Sur-el : gunadi@ukmc.ac.id ${ }^{1}$, kristojb@ukmc.ac.id², arief_arieffianto@yahoo.com ${ }^{3}$
}

\begin{abstract}
Tic-Tac-Toe is one of the board games. It is played by filling the columns on the board with $X$ or $O$ in such a way as to form parallel lines vertically, horizontally and diagonally. This study aims to design Non-Player Characters (NPC) in the tic-tac-toe game with the minimax algorithm. The Tic-tac-toe game will be designed with two game modes: easy and minimum random modes. While in minimax NPC mode will determine the best step. The game development process of the tic-tac-toe application is based on a linear sequence process model. In the analysis phase, the NPC will be designed based on the concept of minimax. Software modeling was designed using Unified Modeling Language (UML), and coded with Visual Basic programming. Our tests show that NPCs with the Minimax algorithm can work well.
\end{abstract}

Keywords: tic-tac-toe, minimax, non-player character

\begin{abstract}
Abstrak : Tic-Tac-Toe adalah salah satu permainan papan. Itu dimainkan dengan mengisi kolom di papan tulis dengan $X$ atau $O$ sedemikian rupa sehingga membentuk garis paralel secara vertikal, horizontal dan diagonal. Penelitian ini bertujuan untuk merancang Karakter NonPemain (NPC) pada game tic-tac-toe dengan algoritma minimax. Game Tic-tac-toe akan dirancang dengan dua mode permainan: mode acak mudah dan minimum. Sedangkan pada mode minimax NPC akan menentukan langkah terbaik. Proses permainan pengembangan aplikasi tictac-toe didasarkan pada model proses linear urutan. Pada tahap analisis, NPC akan dirancang berdasarkan konsep minimax. Pemodelan perangkat lunak dirancang dengan menggunakan Unified Modeling Language (UML), dan diberi kode dengan pemrograman Visual Basic. Pengujian kami menunjukkan NPC dengan algoritma minimax dapat bekerja dengan baik.
\end{abstract}

Kata kunci: tic-tac-toe, minimax, non-player character

\section{PENDAHULUAN}

Perkembangan ilmu pengetahuan dan teknologi kian pesat. Salah satu jenis perkembangan ilmu pengetahuan dan teknologi adalah perkembangan pada dunia game [1]. Bermain game merupakan salah satu aktifitas yang sangat disukai oleh sebagian besar masyarakat. Dengan berkembangnya teknologi sekarang ini, game-game ini tidak hanya dapat kita jumpai pada kehidupan nyata, tapi juga dapat kita jumpai didalam permainan berbasis komputer. Salah satu jenis permainan komputer yaitu board game [2,3].

Tic-tac-toe merupakan permainan berjenis board-game berukuran matriks bujur sangkar. Diandaikan papan permainan berukuran 3 x 3 , maka setiap pemain harus meletakkan bidakbidanya pada sel-sel papan sedemikian hingga tiga bidak secara berturutan membentuk garis horisontal, vertikal, ataupun juga diagonal. Permainan ini harus dimainkan oleh 2 orang pemain $[4,5,6]$. Pada Tic-tac-toe berbasis komputer, salah satu pemain dapat diperankan 
oleh komputer [3]. Penelitian ini bertujuan untuk mendesain non-player character (NPC) yang akan bertindak sebagai pemain yang diperankan oleh komputer.

Permainan papan (board game) merupakan jenis permainan yang dimainkan di atas papan dimana bidak diletakkan di atasnya. Bidak dalam permainan ini mampu berpindah tempat ataupun dimakan oleh bidak lawan, sesuai dengan peraturan yang berlaku pada permainan. Pada umumnya permainan ini berbasis strategi, keberuntungan ataupun gabungan dari kedua hal tersebut [7]. Permainan catur misalnya, untuk dapat memenangkannya diperlukan strategi dalam menempatkan bidakbidaknya. Tetapi, permainan ular tangga, hanya mengandalkan keberuntungan angka dadu yang muncul. Sedangkan Tic-Tac-Toe digolongkan sebagai permainan papan yang melibatkan strategi untuk mencapai kemenangan.

\begin{tabular}{|c|c|}
\hline Menang & 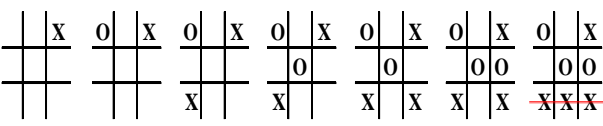 \\
\hline Seri & 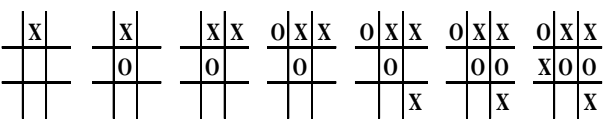 \\
\hline Kalah & 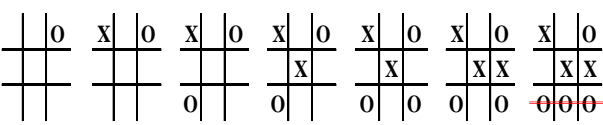 \\
\hline
\end{tabular}

Gambar 1. Kondisi akhir permainan untuk bidak X

Papan permainan tic-tac-toe berupa sel-sel matriks berukuran $\mathrm{n} x \mathrm{n}$. Pada kondisi awal permainan, papan permainan kosong. Setelah itu pemain saling bergantian meletakkan bidaknya pada sel-sel papan permainan Kondisi akhir permainan adalah: menang, seri, dan kalah
(Gambar 1). Misalkan papan permainan berukuran 3 x 3 . Kondisi menang (untuk bidak X) akan tercapai apabila menjadi pemain pertama yang dapat meletakkan 3 bidak (X) dalam posisi sejajar (vertikal, horisontal, diagonal). Kondisi seri akan tercapai apabila hingga seluruh sel-sel tersisi, kedua pemain tidak dapat meletakkan 3 bidaknya pada posisi sejajar. Sedangkan kondisi kalah (untuk bidak $\mathrm{X}$ ) tercapai apabila pemain lawan yang pertama kali meletakkan 3 bidak (O) pada posisi sejajar [3].

Agar komputer dapat berperan sebagai pemain, diperlukan sebuah algoritma yang berfungsi untuk mencari langkah terbaik dari situasi sekarang. Salah satu algoritma yang paling banyak digunakan adalah algoritma Minimax. Algoritma ini sangat cocok untuk permainan dengan dua pemain. Algoritma ini digunakan untuk memilih langkah terbaik yang diberikan, dimana kedua pemain saling berusaha untuk memenangkan permainan [7].

Minimax merupakan salah satu teknik permainan yang terkenal. Minimax menggunakan teknik pencarian depth-first search dengan kedalaman terbatas, dan fungsi evaluasi yang digunakan adalah fungsi evaluasi statis, dengan mengasumsikan bahwa lawan akan membuat langkah terbaiknya yang dapat dilakukan, algoritma minimax cocok digunakan untuk permainan catur, Othello, checkers, dan Tic-Tac-Toe $[4,8]$.

Penerapan algoritma Minimax dalam tictac-toe dibuat berdasarkan prosedur Minimax untuk mendapatkan langkah terbaik dari posisi yang ada. Setiap posisi memiliki nilai yang dapat dihasilkan dari langkah terbaik, dengan 
berasumsi bahwa pemain akan selalu memaksimalkan nilai, ketika lawan akan mencoba untuk meminimalkannya, sehingga akan menghasilkan pohon permainan yang berisi semua kemungkinan tersebut (Gambar 2). Keuntungan penggunaan algoritma Minimax adalah mampu menganalisis semua kemungkinan posisi permainan untuk menghasilkan keputusan terbaik dengan mencari langkah yang akan membuat lawan mengalami kerugian. Fungsi evaluasi yang digunakan adalah fungsi evaluasi statis dengan asumsi lawan akan melakukan langkah terbaik yang mungkin. Pada Minimax dikenal adanya istilah gerakan pemain MAX melawan pemain MIN [9].

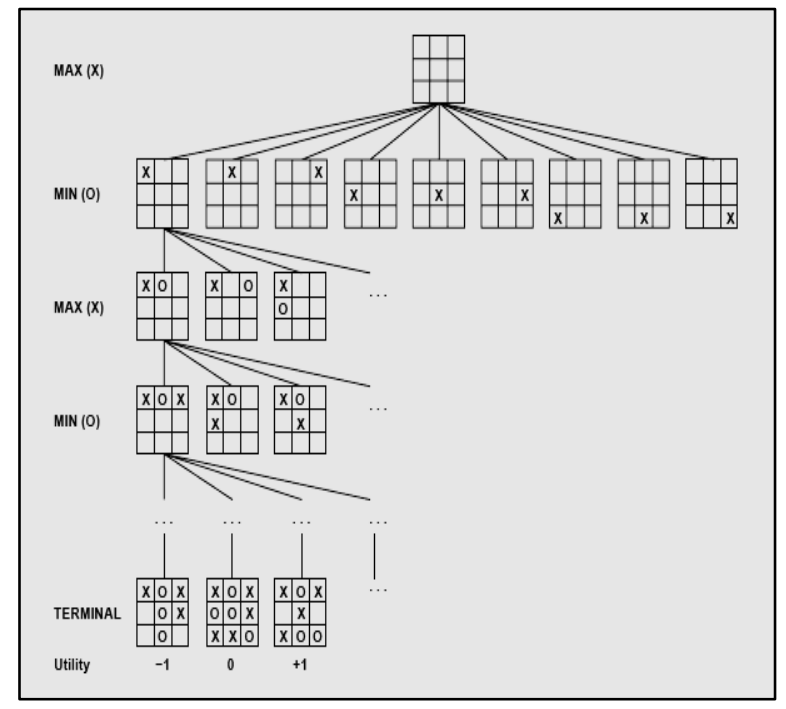

Gambar 2. Pohon permainan tic-tac-toe

Pohon (tree) merupakan graf yang masing-masing node-nya (kecuali root) hanya memiliki satu induk (parent), dengan kata lain tidak memiliki cycle. Node yang tidak memiliki child disebut terminal node. Metode pencarian yang umumnya digunakan pada pohon pencarian adalah breadth-first search (BFS) atau depthfirst search (DFS). Karena ruang pencarian pohon permainan Tic-Tac-Toe cukup besar, maka penggunaan metode BFS dirasa tidak tepat, sebab metode ini membutuhkan kapasitas memori yang besar. Berbeda dengan metode DFS yang hanya membutuhkan memori relatif kecil.

\section{METODOLOGI PENELITIAN}

Metode penelitian ini mengacu pada model proses sekuensial linier [10]. Dalam model ini (Gambar 3), pengembangan perangkat lunak dilakukan secara sistematik dan linier, yang dimulai dari aktivitas analisis, desain, pengkodean dan pengujian perangkat lunak. Aktivitas analisis dan desain merupakan bagian dari aktivitas rekayasa sistem. Setiap model analisis yang dihasilkan akan diterjemahkan ke bentuk desain yang bersesuaian (Gambar 4).

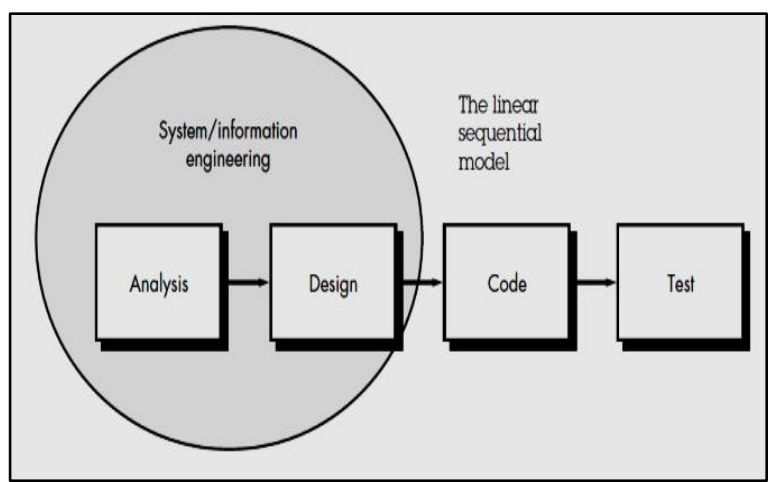

Gambar 3. Model sekuensial linier

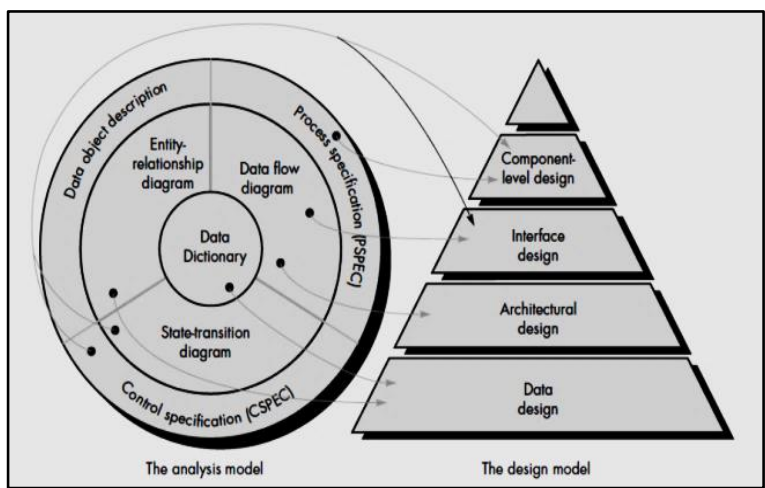

Gambar 4. Hubungan tahap analisis dan desain 
Secara umum tahapan-tahapan dalam penelitian ini mengacu pada tahapan dalam model sekuensial linier seperti yang diuraikan pada Tabel 1.

Tabel 1. Tahapan penelitian

\begin{tabular}{|c|c|}
\hline Tahap & Kegiatan \\
\hline Analysis & $\begin{array}{l}\text { Menentukan aturan permaian } \\
\text { Analisis pergerakan NPC }\end{array}$ \\
\hline Design & $\begin{array}{l}\text { Desain algoritma minmax } \\
\text { Desain perangkat lunak dengan } \\
\text { menggunakan unified modeling } \\
\text { language }\end{array}$ \\
\hline Code & $\begin{array}{l}\text { Membangun aplikasi dengan bahasa } \\
\text { pemrograman Visual Basic }\end{array}$ \\
\hline Test & $\begin{array}{l}\text { Melakukan uji perangkat lunak } \\
\text { Melakukan uji statistik }\end{array}$ \\
\hline
\end{tabular}

\section{HASIL DAN PEMBAHASAN}

\subsection{Aturan Permainan}

Aturan permainan tic-tac-toe yang diterapkan sebagai berikut.

a. Besar papan permainan berukuran $3 \times 3$ dengan deret kemenangan 3 bidak.

b. Pemain dalam permainan ini dibatasi untuk satu lawan satu, dilakukan bergiliran antara manusia dan komputer (NPC).

c. Pemain manusia (player) akan dihalangi oleh NPC untuk mencapai tujuan (goal).

d. Untuk memberikan langkah, setiap pemain harus mengisi bidak dengan simbol pemain masing-masing, biasanya $\mathrm{X}$ atau $\mathrm{O}$.

e. Setiap pemain hanya mempunyai satu kali kesempatan pada setiap giliran.

f. Bidak yang sudah terisi tidak bisa ditimpa oleh bidak lain pada langkah berikutnya.

g. Langkah yang sudah diambil tidak dapat dibatalkan atau diganti dengan langkah yang lain. h. Tujuan dari permainan ini adalah untuk mendapatkan deret dengan tiga 3 bidak yang sama secara horizontal, vertikal atau diagonal.

i. Pemenang ditentukan oleh pemain yang pertama kali menyusun deret tersebut.

j. Permainan akan dihentikan jika sudah ada pemenang.

\begin{tabular}{|l|l|l|}
\hline$(0,0)$ & $(0,1)$ & $(0,2)$ \\
\hline$(1,0)$ & $(1,1)$ & $(1,2)$ \\
\hline$(2,0)$ & $(2,1)$ & $(2,2)$ \\
\hline
\end{tabular}

Gambar 5. Papan permaian dan nilai index

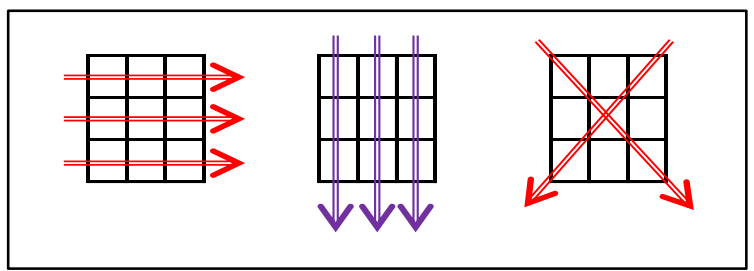

Gambar 6. Kemungkinan goal

Papan permainan tic-tac toe terdiri atas 9 kotak. Untuk memudahkan proses eksekusi algoritma, setiap kotak akan diberi indeks yang terdiri atas indeks baris (i) dan indeks kolom (j). Gambar 5 memperlihatkan papan permainan dan nilai indeksnya. Goal atau tujuan permainan tercapai apabila salah satu pemain telah menempatkan 3 bidak dalam deret sejajar. Ada 8 kemungkinan deretan yang terbentuk (Gambar 6), yakni: 3 deret dalam posisi horisontal, 3 deret dalam posisi vertikal dan 3 deret dalam posisi diagonal 


\subsection{Analisis Pergerakan NPC dan Desain Algoritma}

Pergerakan NPC akan dirancang dalam dua mode, yakni mode random dan mode minimax. Pada mode random, NPC akan meletakkan bidak secara acak pada posisi yang kosong (null). Sedangkan pada mode minimax, NPC akan menentukan langkah terbaik berdasarkan algoritma minimax. Algoritma minimax memiliki parameter sebagai berikut.

a. Initial state; merupakan keadaan papan sebelum algoritma dijalankan

b. Player; pemain mana yang mendapat giliran meletakkan bidak pada sebuah state

c. Action; merupakan himpunan pergerakan yang dapat dilakukan player

d. Result; merupakan keadaan papan setelah sebuah action dilakukan.

e. Terminal test; merupakan fungsi pengecekan tujuan. Apakah kondisi kemenangan telah terpenuhi?

f. Utility function; merupakan nilai evaluasi kemungkinan kemenangan.

Selain itu, setiap level pada pohon pencarian akan ditandai sebagai level MAX dan level MIN. Level MAX mewakili giliran NPC untuk meletakkan bidak, sedangkan level MIN mewakili giliran pemain lawan.

Sebagai ilustrasi, dapat diperhatikan Gambar 7. Misalkan NPC mengendalikan bidak $\mathrm{X}$ dan pemain lawan mengendalikan bidak $\mathrm{O}$. Initial state (disimbolkan dengan node A, sebagai node induk) merupakan keadaan papan setelah pemain lawan meletakkan bidak O pada kotak $(1,0)$. Giliran main berikutnya adalah NPC yang meletakkan bidak. Terdapat 5 action yang mungkin dilakukan oleh NPC, yakni

a. $a_{1}$ : meletakkan bidak $X$ pada $\operatorname{kotak}(0,2)$,

b. $a_{2}$ : meletakkan bidak $X$ pada $\operatorname{kotak}(1,2)$,

c. $a_{3}$ : meletakkan bidak $X$ pada kotak $(2,0)$,

d. $a_{4}$ : meletakkan bidak $X$ pada $\operatorname{kotak}(2,2)$.

e. $a_{5}$ : meletakkan bidak $X$ pada $\operatorname{kotak}(2,1)$ (tidak digambarkan dalam ilustrasi).

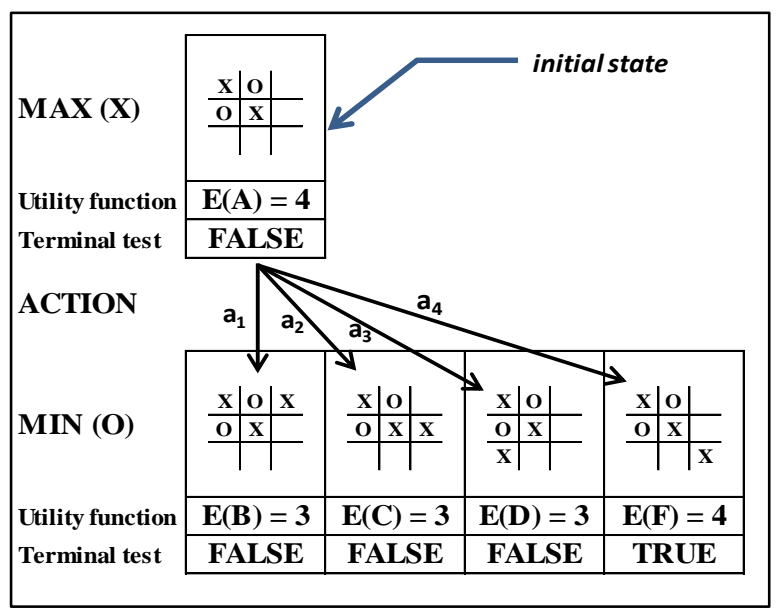

Gambar 7. Pohon pencarian tic-tac-toe

Setelah salah satu aksi dilakukan keadaaan papan akan berubah (result). Terminal test diperoleh dengan memeriksa posisi bidak pada papan permainan. Terminal test akan bernilai TRUE jika salah satu kondisi berikut terpenuhi:

a. nilai indeks baris dari ketiga bidak adalah sama atau,

b. nilai indeks kolom ketiga bidak adalah sama atau,

c. untuk setiap bidak, nilai indek baris sama dengan nilai indeks kolomnya atau,

d. untuk setiap bidak, jumlah nilai indeks baris ditambah nilai indeks kolom sama dengan 2.

Permainan akan dihentikan jika terminal test telah bernilai TRUE. Gambar 8 memperlihatkan desain pseudocode untuk mengecek terminal test. 


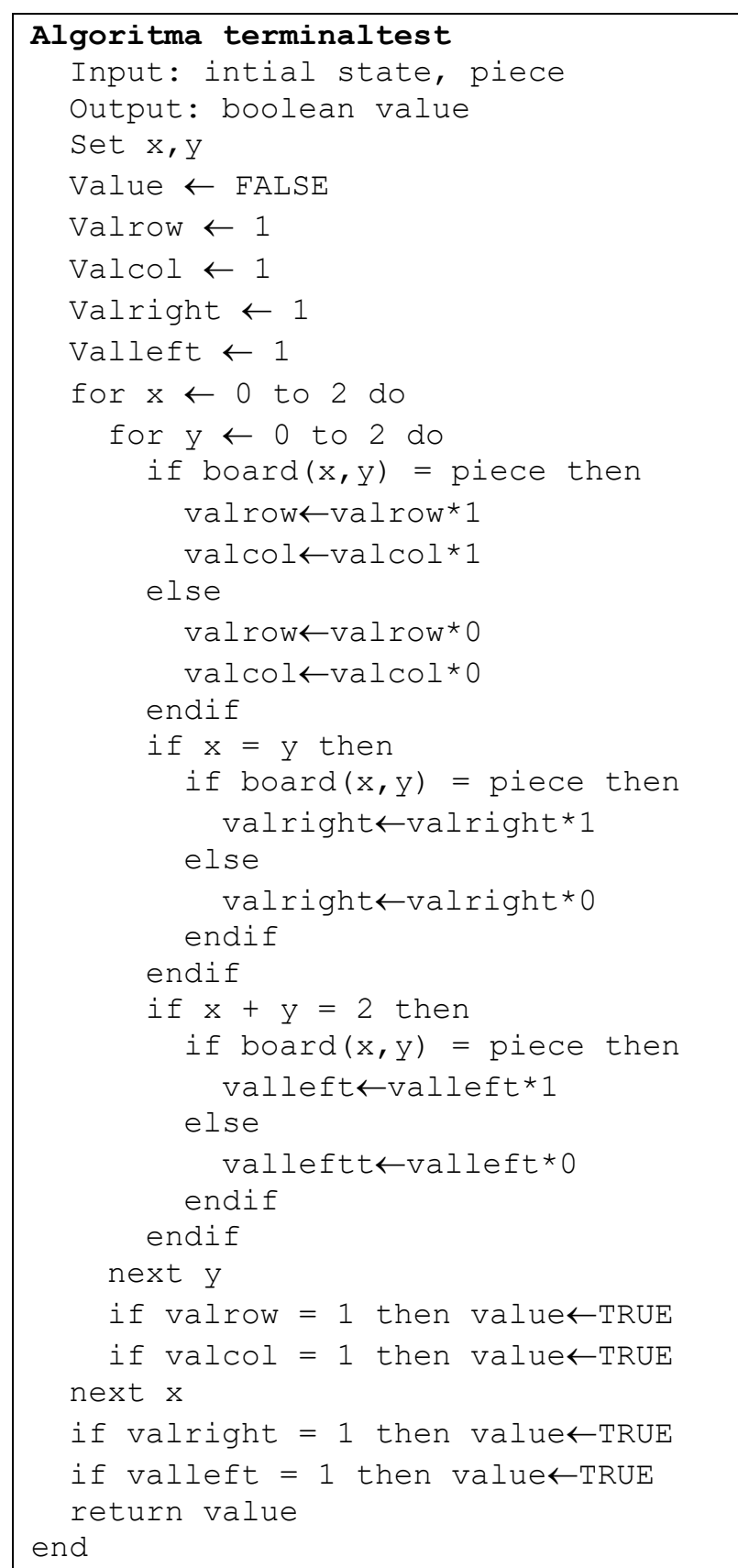

\section{Gambar 8. Pseudocode terminal test}

Untuk memilih sebuah aksi, NPC akan membangun pohon pencarian sedalam 1 level (one-ply search). Setelah itu NPC akan mengevaluasi nilai utility function dari setiap node anak. Nilai utility function (E) diperoleh dengan cara menghitung kemungkinan kemenangan yang dapat dicapai NPC (B1) dikurangi kemungkinan kemenangan yang dapat dicapai pemain lawan (B2). Sehingga secara matematis dapat dituliskan seperti pada persamaan (1).

$$
E=B 1-B 2
$$

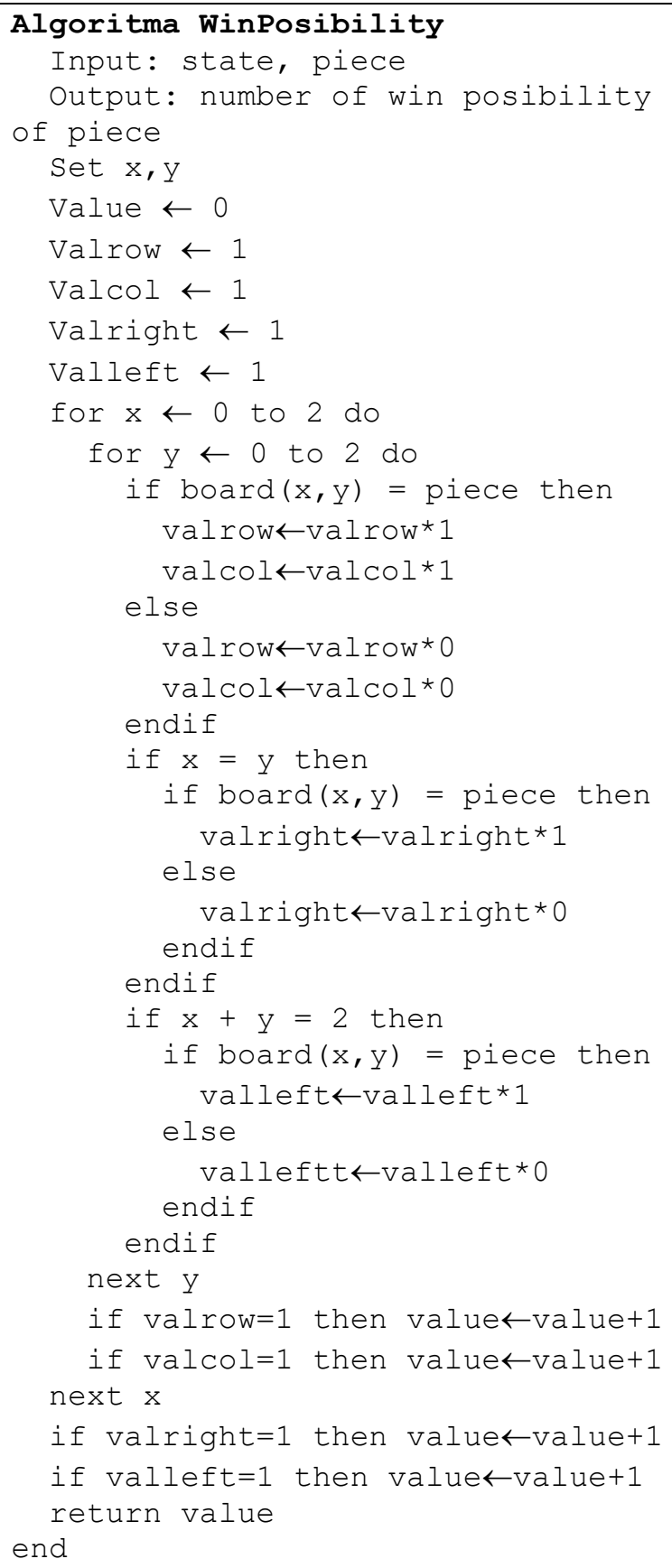

Gambar 9. Pseudocode kemungkinan kemenangan

Gambar 9 menampilkan pseudocode untuk menghitung kemungkinan kemenangan setiap pemain. Sedangkan Gambar 10 
menampilkan pseudocode untuk mendapatkan nilai Utility Function.

Sebagai ilustrasi, dimisalkan pada Gambar 7, A adalah node induk dengan node anaknya adalah $\mathrm{B}$, $\mathrm{C}, \mathrm{D}$, dan F. Nilai E dihitung mulai dari node-node tersebut. Nilai utility function untuk node B dapat dihitung sebagai berikut. Kemungkinan kemenangan NPC adalah deret $[(0,0),(1,1),(2,2)],[(0,2),(1,1)$, $(2,0)],[(0,2),(1,2),(2,2)]$, dan [(2,0), $(2,1),(2,2)]$. Dengan demikian ada 4 kemungkinan menang bagi NPC (B1 =4). Sedangkan bagi pemain lawan, hanya ada 1 kemungkinan menang $(\mathrm{B} 2=1)$, yakni pada deret $[(2,0),(2,1),(2,2)]$. Dengan demikian $\mathrm{E}(\mathrm{B})=4$ $-1=3$. Dengan cara yang sama, nilai utility function untuk node $\mathrm{C}, \mathrm{D}$, dan $\mathrm{F}$ dapat dihitung. Setelah seluruh nilai utility function pada node anak dihitung, maka nilai utility function pada node induk dapat dihitung.

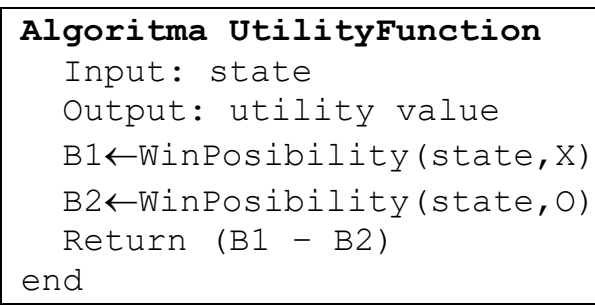

\section{Gambar 10. Pseudocode utility function}

Misalkan, $\mathrm{E}(\mathrm{B})=3, \mathrm{E}(\mathrm{C})=3, \mathrm{E}(\mathrm{D})=3$, dan $\mathrm{E}(\mathrm{F})=4$. Karena node induk (node $\mathrm{A}$ ) berada pada posisi MAX, maka $\mathrm{E}(\mathrm{A})=\operatorname{MAX}[\mathrm{E}(\mathrm{B}), \mathrm{E}(\mathrm{C}), \mathrm{E}(\mathrm{D})$, $\mathrm{E}(\mathrm{F})]=\operatorname{MAX}[3,3,3,4]=4$. Dengan demikian, NPC akan memilih action a4 sebagai langkah terbaik. Gambar 11 menampilkan algoritma FindMax untuk menentukan langkah terbaik.

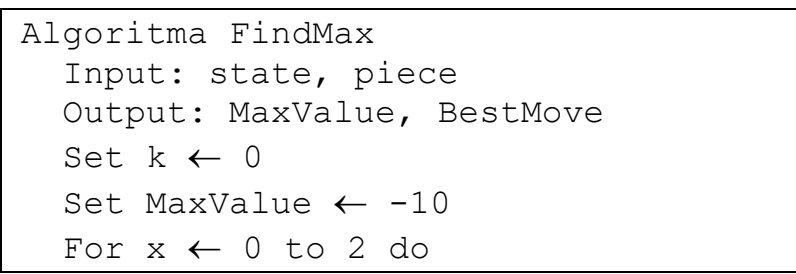

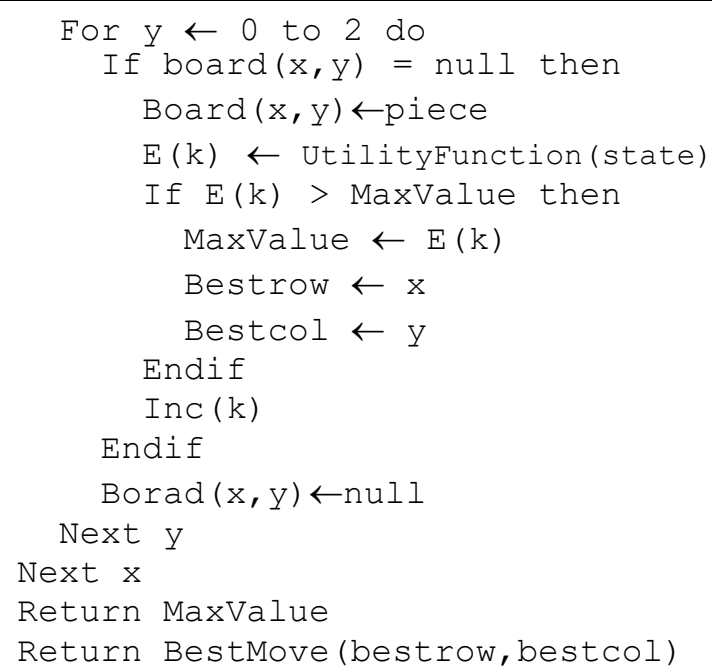

\section{Gambar 11. Pseudocode FindMax}

\subsection{Desain Perangkat Lunak dan Kode}

Perangkat lunak dirancang dengan menggunakan Unified Modeling Language (UML). Dalam hal ini kami menggunakan empat diagram UML yakni use case diagram, class diagram, activity diagram, dan sequence diagram. Pada Gambar 12 diperlihatkan use case diagram untuk perangkat lunak yang akan dibangun. Use case diagram dilengkapi dengan skenario untuk menjelaskan aliran aksi yang dijalankan. Terdapat tiga sekenaio yang dirancang yakni skenario new game, skenario option dan skenario exit. Pada Tabel 2 tersaji contoh skenario untuk jika aktor (player) memilih aksi new game.

Pada Gambar 13 disajikan class diagram yang dirancang untuk palikasi tic-tac-toe. Diagram aktivitas (activity diagram) juga dirancang untuk tiga aktivitas utama, yakni new game, diagram aktivitas option, dan diagram aktivitas proses exit. Pada Gambar 14 disajikan contoh diagram aktivitas. 


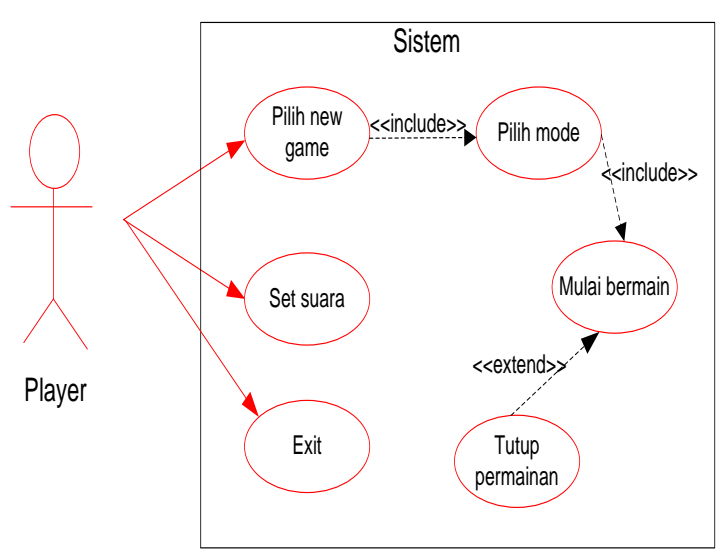

Gambar 12. Use case diagram aplikasi tic-tac-toe

Tabel 2. Skenario new game

\begin{tabular}{|c|c|}
\hline $\begin{array}{l}\text { Aktor yang } \\
\text { Menggunakan }\end{array}$ & Pengguna \\
\hline Fungsi & $\begin{array}{l}\text { Melakukan permainan } t i c-t a c- \\
\text { toe pada awal permainan }\end{array}$ \\
\hline Deskripsi & $\begin{array}{l}\text { Memainkan permainan tic-tac- } \\
\text { toe }\end{array}$ \\
\hline Kondisi Awal & Halaman menu utama \\
\hline \multicolumn{2}{|c|}{ Mekanisme Kerja } \\
\hline \multirow[t]{2}{*}{ Aktor } & Sistem \\
\hline & 1 Tampil form menu utama \\
\hline \multicolumn{2}{|c|}{2 Klik tombol new game } \\
\hline & 3 Tampil form level \\
\hline \multicolumn{2}{|c|}{$\begin{array}{l}4 \text { Klik level yang } \\
\text { diinginkan }\end{array}$} \\
\hline & 5 Tampil form permainan \\
\hline & $\begin{array}{l}6 \text { Menentukan pemain } \\
\text { pertama }\end{array}$ \\
\hline & $\begin{array}{l}7 \text { Aktor jalan terlebih } \\
\text { dahulu }\end{array}$ \\
\hline \multicolumn{2}{|c|}{$\begin{array}{l}8 \text { Aktor mengisi kotak } \\
\text { kosong }\end{array}$} \\
\hline & $\begin{array}{l}9 \text { Memeriksa dan mengisi } \\
\text { kotak kosong }\end{array}$ \\
\hline \multicolumn{2}{|l|}{ Alternatif 1} \\
\hline & $\begin{array}{l}7 \text { Sistem jalan terlebih } \\
\text { dahulu }\end{array}$ \\
\hline & $\begin{array}{l}8 \text { Sistem mengisi kotak } \\
\text { kosong }\end{array}$ \\
\hline \multicolumn{2}{|c|}{$\begin{array}{l}9 \text { Aktor mengisi kotak } \\
\text { kosong }\end{array}$} \\
\hline & $\begin{array}{l}10 \text { Selalu bergiliran sampai } \\
\text { ada yang menang }\end{array}$ \\
\hline Kondisi Akhir & $\begin{array}{l}\text { Tampil Pemberitahuan } \\
\text { sistem menang atau aktor } \\
\text { menang }\end{array}$ \\
\hline
\end{tabular}

Selain menggunakan diagram use case dan diagram aktivitas untuk menggambarkan perilaku pengrakat lunak, kami juga merancang perilaku interaksi perangkat lunak dengan menggunakan sequence diagram. Mengacu pada tiga aktivitas utama, sequence diagram juga dirancang untuk tiga aktivitas tersebut. Gambar 15 menampilkan contoh sequence diagram yang dirancang.

\begin{tabular}{|l|}
\multicolumn{1}{|c|}{ Class $1:: T i c T a c T o e$} \\
\hline -waktu : Integer \\
-JumlahPemainMenang : Integer \\
-JumlahAIMenang : Integer \\
-JumlahSeri : Integer \\
-Turn : Integer \\
--KondisiMenang : Integer \\
-KondisiMain : Integer \\
-BidakPemain : String \\
-BidakAI : String \\
-NomorTurn : Integer \\
-LangkahGame : Integer \\
-MaxLangkahPemain : Integer \\
-LeveIPermainan : Integer \\
-LangkahMenang : Integer \\
\hline +InitVariabelDefaultGame() \\
+SetNextTurn() \\
+InitGame() \\
+SetLangkahAl() \\
+AIEasyMove()() \\
+AINormalMove() \\
+AlHardMove() \\
+AmbilLangkahCegah() \\
+CekMinimax() \\
+GetMinimax() \\
+CekMenang() \\
+exit_Click() \\
+newgame_Click() \\
+option_Click() \\
+easy_Click() \\
+normal_Click() \\
+hard_Click() \\
+InisialisasiGame() \\
+SetTampilan() \\
+SetTurn() \\
\hline
\end{tabular}

Gambar 13. Class diagram aplikasi tic-tac-toe 


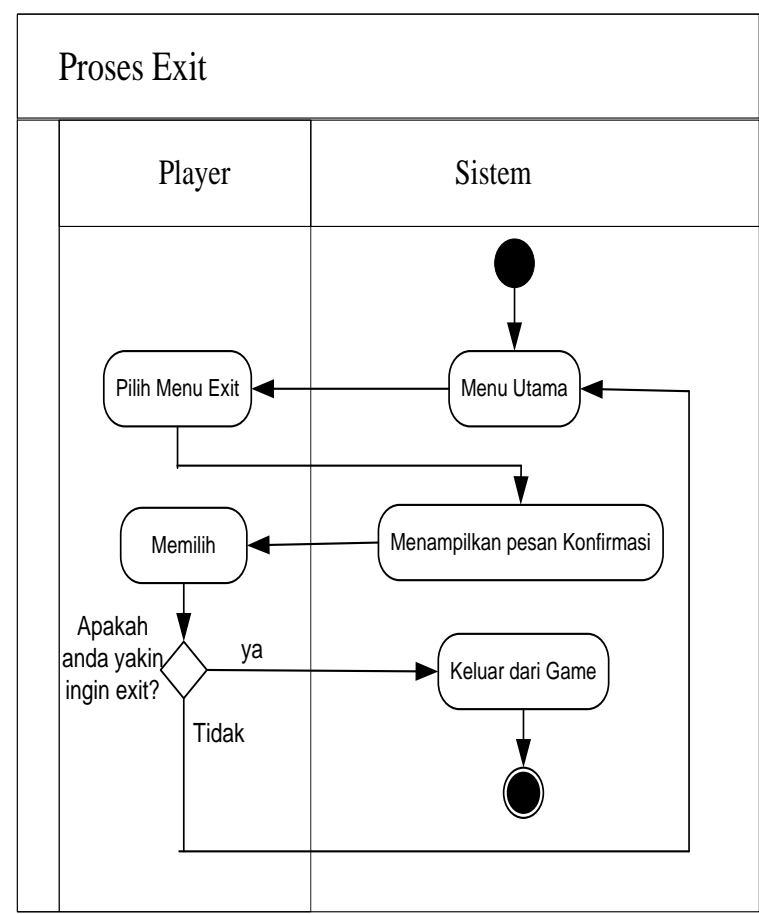

Gambar 14. Activity diagram proses exit

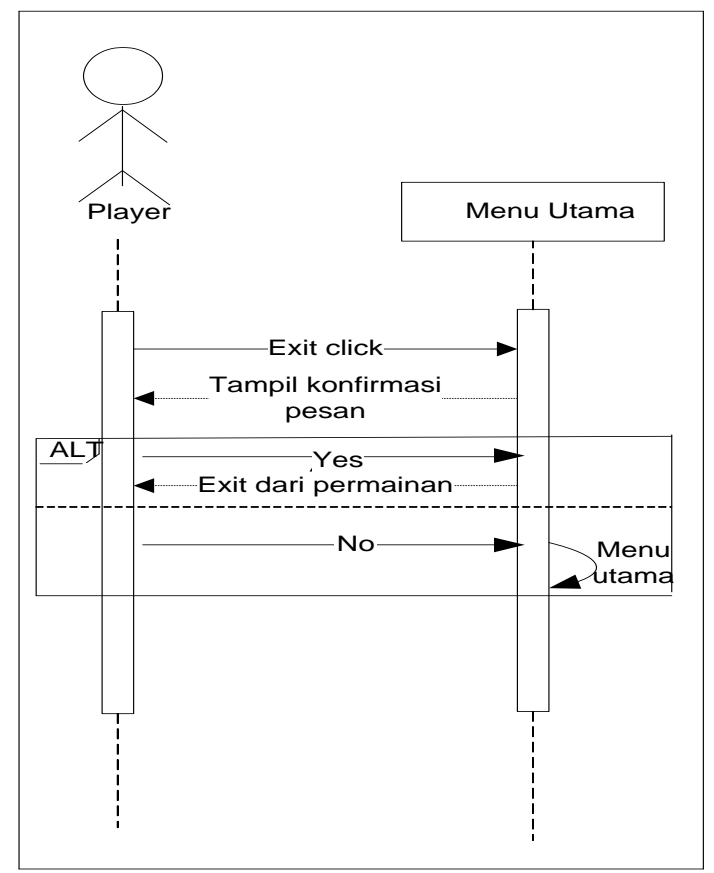

Gambar 15. Sequence diagram proses exit

Aplikasi tic-tac-toe ini dibangun dengan menggunakan pemrograman Visual Basic dan dapat dijalankan pada platform Windows. Gambar 16 dan Gambar 17 menampilkan contoh antarmuka pemakai dari aplikasi yang dibangun.

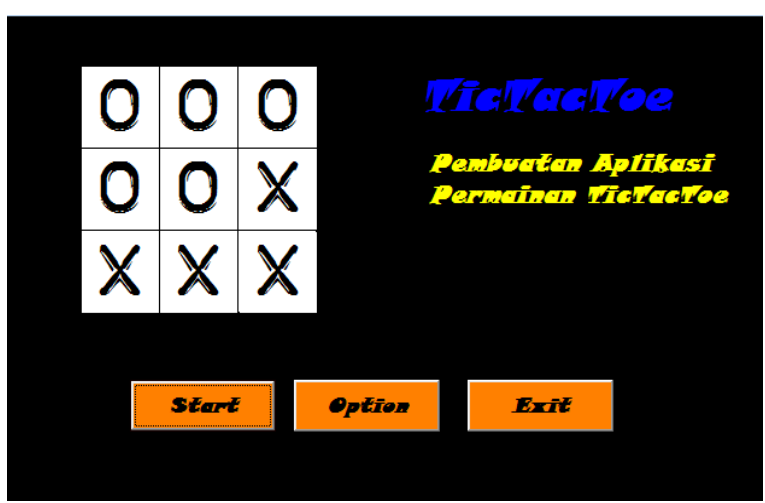

Gambar 16. Tampilan awal aplikasi

\subsection{Pengujian Perangkat Lunak}

Pengujian perangkat lunak dilakukan dengan teknik whitebox testing dan blackbox testing.

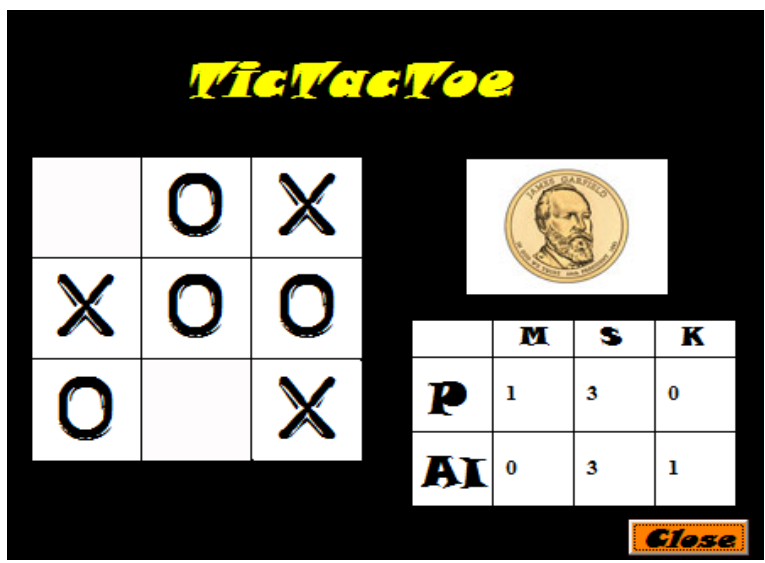

Gambar 17. Antarmuka aplikasi

Pengujian whitebox dilakukan untuk memastikan bahwa semua jalur independen dari suatu modul telah dilalui paling sedikit satu kali. Pada aplikasi ini pengujian whitebox yang dilakukan adalah pengujian basis path dan kemudian menghitung nilai cyclomatic complexity. Berdasarkan flowgraph yang disusun, diperoleh jumlah node $(\mathrm{N})$ sebanyak 23 dan jumlag edge (E) sebanyak 30. Dengan demikian diperoleh nilai $V(G)$ $=\mathrm{E}-\mathrm{N}+2=9$. Hal ini berarti bahwa aplikasi yang dibangun memiliki prosedur yang terstruktur baik, stabil, dan resiko rendah. 
Pengujian blackbox dilakukan untuk memastikan bahwa semua fungsi-fungsi suatu perangkat lunak telah berjalan dengan benar. Pada aplikasi ini pengujian blackbox dilakukan dengan memeriksa kesalahan antarmuka pemakai. Tabel 3 memperlihatkan hasil pengujian blackbox pada antarmuka permainan (form permainan).

Pengujian secara statistik juga dilakukan untuk melihat seberapa baik kinerja algoritma yang telah dirancang. Pengujian dilakukan dengan melibatkan 99 kali percobaan memainkan aplikasi tic-tac-toe. Hasilnya (Tabel 4) menunjukkan bahwa pada mode random, player dapat memenangkan seluruh sesi permainan $(100 \%)$. Sedangkan pada mode minimax, player tingkat kemenangan player menurun menjadi 67,6\%. Hal ini menunjukkan bahwa algoritma minimax dapat bekerja dengan baik sebagai NPC.

Tabel 3. Hasil pengujian balckbox form permainan

\begin{tabular}{|c|c|c|c|c|}
\hline No & $\begin{array}{c}\text { Item } \\
\text { Pengujian }\end{array}$ & $\begin{array}{l}\text { Hasil yang } \\
\text { diharapkan }\end{array}$ & $\begin{array}{c}\text { Hasil } \\
\text { Implementasi }\end{array}$ & Keterangan \\
\hline 1. & Koin Putar & $\begin{array}{l}\text { Sistem } \\
\text { Aktif. }\end{array}$ & $\begin{array}{l}\text { Tampilan } \\
\text { Pesan "AI } \\
\text { First" }\end{array}$ & $\begin{array}{l}\text { Sesuai yang } \\
\text { diharapkan }\end{array}$ \\
\hline 2. & $\begin{array}{l}\text { Bidak yang } \\
\text { dikeluarkan. }\end{array}$ & $\begin{array}{l}\text { Sistem } \\
\text { Aktif. }\end{array}$ & $\begin{array}{l}\text { User klik } \\
\text { kolom kosong } \\
\text { dan bidak } \\
\text { muncul }\end{array}$ & $\begin{array}{l}\text { Sesuai yang } \\
\text { diharapkan }\end{array}$ \\
\hline 3. & Papan score & $\begin{array}{l}\text { Sistem } \\
\text { Aktif. }\end{array}$ & $\begin{array}{l}\text { Tampil score } \\
\text { player dan } \mathrm{AI}\end{array}$ & $\begin{array}{l}\text { Sesuai yang } \\
\text { diharapkan }\end{array}$ \\
\hline 4. & Pilih Back. & $\begin{array}{l}\text { Sistem } \\
\text { Aktif. }\end{array}$ & $\begin{array}{l}\text { Tampil form } \\
\text { Level. }\end{array}$ & $\begin{array}{l}\text { Sesuai yang } \\
\text { diharapkan }\end{array}$ \\
\hline 5. & Pilih Keluar & $\begin{array}{l}\text { Sistem } \\
\text { Aktif. }\end{array}$ & $\begin{array}{l}\text { Tampil form } \\
\text { Menu Utama. }\end{array}$ & $\begin{array}{l}\text { Sesuai yang } \\
\text { diharapkan }\end{array}$ \\
\hline
\end{tabular}

Tabel 4. Hasil pengujian statistik

\begin{tabular}{ccc}
\hline & \multicolumn{2}{c}{ Mode } \\
\cline { 2 - 3 } Player & Random & Minimax \\
\hline Menang & $100 \%$ & $67,6 \%$ \\
Seri & $0 \%$ & $30,3 \%$ \\
Kalah & $0 \%$ & $2,02 \%$ \\
\hline
\end{tabular}

\section{KESIMPULAN}

Berdasarkan hasil penelitian dapat diambil kesimpulan berikut.

a. Algoritma minimax dapat digunakan sebagai NPC dalam permainan tic-tac-toe secara khusus dan secara umum permainan papan yang melibatkan dua player.

b. Dalam penelitian ini, tingkat kedalaman pohon pencarian hanya sebesar satu tingkat, pada penelitian lanjutan tingkat kedalaman pohon pencarian dapat ditingkatkan.

\section{DAFTAR PUSTAKA}

[1] R. P. Kusrachmadi, Rizky Yuniar Hakkun, and Idris Winarno, "Pengenalan Jaringan Komputer Berbasis Role Playing Game Menggunakan RMXP dan RGSS," Surabaya, Tugas Akhir 2013.

[2] Muhammad Kurniawan, Afib Pamungkas, and Salman Hadi, "Algoritma Minimax Sebagai Pengambila Keputusan Dalam Game Tic-Tac-Toe," in Seminar Nasional Teknologi dan Multimedia, Yogayakarta, 2016.

[3] R. Kristoforus Jawa Bendi, "Penggunaan Fungsi Heuristik Sederhana Pada Permainan Tic-Tac-Toe," in Prosiding Seminar Nasional Inovasi Dan Aplikasi Teknologi Di Industri, Malang, 2017, pp. A18.1-A18.7.

[4] Umair Z Ahmed, Krishnendu Chatterjee, and Gulwani Sumit, "Automatic generation of alternative starting positions for simple traditional board games," in National Conference on Artificial Intelligence, Austin, Texas USA, 2015, pp. 1-8.

[5] S. Karamchandani, P. Gandhi, O. Pawar, and S. Pawaskar, "A simple algorithm for designing an artificial intelligence based Tic Tac Toe game," in Proceeding of International Conference on Pervasive Computing, 2015, pp. 1-4.

[6] S Kosasi, "Permainan Papan Strategi Menggunakan Algoritma Minimax," in 
Seminar Nasional Teknologi Informasi, Komunikasi dan Industri, 2014, pp. 105112.

[7] E Jayadi, MAF Rachman, and $M$ Yuliansyah, "Aplikasi Game Tic Tac Toe 6x6 Berbasis Android Menggunakan Algoritma Minimax Dan Heuristic Evaluation," in Seminar Nasional Teknologi Informasi dan Multimedia, 2016, pp. 91-96.

[8] Dicky Herman Firmansyah, Nana Juhana, and Irfan Maliki, "Implementasi Algoritma Minimax Pada Permainan Tic-Tac-Toe Skala 9x9," Bandung, Skripsi 2009.

[9] Nur Jannah, "Analisis dan Implementasi Algoritma Minimax dengan Optimasi Alpha-Beta Pruning pada Permainan Five In Row," Medan, Skripsi 2010.

[10] Roger S. Pressman, Software Engineering: A Practitioner's Approach.: McGraw-Hill, 2001. 